\title{
Comparison of 27 G Quincke and 25 G Quincke Needles for Post Dural Puncture Headache in Caesarean Section
}

\author{
Islam MA ${ }^{1}$, Begum $A^{2}$, Shahida $\mathrm{SM}^{3}$
}

\begin{abstract}
Introduction: Although modern anaesthesiology has made great progress in the last decades and spinal anaesthesia is popular for its effectiveness, Post Dural Puncture Headache (PDPH) is a significant and well known complication of spinal anaesthesia that may be incapacitating for patients. A few decades ago less refined and thicker spinal needles were being used and the incidence of PDPH was high. But within the last 15 years more refined and thinner needles have been used and the incidence of PDPH is grossly reduced.
\end{abstract}

Objective: To compare the incidence and severity of post dural puncture headache using $25 \mathrm{G}$ Quincke and $27 \mathrm{G}$ Quincke needle during spinal anaesthesia in case of caesarean section.

Materials and Methods: This randomized prospective study was carried out in the Border Guard Hospital, Dhaka, during the period of January to July, 2015. Patients were selected randomly from the age group of 20-35 years having a pregnancy of at least 34 weeks gestation with a single uncompromised fetus and uncomplicated pregnancy. Patients with a history of migraine, convulsion, cerebrovascular accident, Pre-eclampsia, eclampsia, spinal deformity, coagulopathy or previous neurological disease were excluded. They were randomly allocated into two groups. Each group consisting of 50 patients. Data was collected by interviewing and observation results. Data were processed and analyzed by using statistical test.

Results: There was no statistically significant difference found in age, height, weight and ASA status between two groups. 27G Quincke needle had significantly higher failure rate of successful lumber puncture in first attempt than the 25G Quincke needle $(20 \%$ vs $6 \%, P<0.05)$. There was no difference difference regarding the incidence of intraoperative complications between two groups. The overall incidence of $\mathrm{PDPH}$ was $2(4 \%)$ in group $\mathrm{A}$ and 12 $(24 \%)$ in group $B(P<0.05)$. Decreased severity of headache was noted in the $27 \mathrm{G}$ group Quincke needle. There was no difference regarding the duration of headache in between two groups.

Conclusion: This study suggests that the risk of PDPH was much lower in $27 \mathrm{G}$ Quincke needle as compared to $25 \mathrm{G}$ Quincke needle though it had a higher failure rate of successful lumber puncture in first attempt. For spinal anaesthesia 27G Quincke needle should be used.

Key-words: 27 G Quincke, 25 G Quincke Needle, Post Dural Puncture Headache, Caesarean Section.

\section{Introduction}

Spinal anaesthesia is one of the oldest modalities for providing pain relief in patient undergoing surgery. Its fast and efficient effectiveness in addition to an acceptable complication rate makes it very reliable and safe resulting in a world-wide application ${ }^{1}$. In contrast to this, PDPH remains a troublesome complication of spinal anaesthesia which occurs in $36.5 \%$ of patients receiving spinal anaesthesia ${ }^{2}$. In 1898 Bier suffered and was the first to report post lumber puncture headache (PDPH). He proposed that ongoing leakage of cerebrospinal fluid (CSF) through the dural puncture site was the cause of the headache. This belief is maintained today; it is supposed that CSF production, resulting in low CSF volume and pressure. Up to date there is still no approach which has demonstrated to offer complete prevention or treatment of PDPH. A few decades ago less refined and thicker spinal needle were being used and the incidence of PDPH was high ${ }^{3,4}$. The currently proposed suggestion regarding prevention of PDPH

1. Lt Col Md. Anisul Islam, MBBS, DA, FCPS (Anaesthesia), Anaesthesiologist, Border Guard Hospital, Dhaka 2. Lt Col Amena Begum, MBBS, FCPS (Obs \& Gynae), Gynaecologist, Border Guard Hospital, Dhaka 3. Dr SM Shahida, MBBS, FCPS (Obs \& Gynae), Assistant Professor, Dhaka Medical College. 
consists of choosing the optimal needle size and tip in addition to technique of insertion ${ }^{5}$. The incidence of headache is $70 \%$ if the needle size is between 16 and $19 \mathrm{G}, 40 \%$ if the needle size is between 20 to 22 $G$ and $12 \%$ if the needle size is between 24 to $27 G^{6}$. It is found to be more common after caesarian section in young parturient. They would be benefited greatly from a reduction in the rate of PDPH. Therefore the present study was designed to compare the incidence of post lumber puncture headache after use of $25 \mathrm{G}$ Quincke and $27 \mathrm{G}$ Quincke needle during spinal anaesthesia in case of caesarean section.

\section{Materials and Methods}

This prospective study was carried out in the anaesthesia department of Border Guard Hospital, Peelkhana, Dhaka, Bangladesh, during the period of January to July, 2015. Following Institutional Ethical Committee approval and written informed consent patients were selected randomly from the age group of 20-35 years having a pregnancy of at least 34 weeks gestation with a single uncompromised fetus and uncomplicated pregnancy. Patients with a history of migraine convulsion, cerebrovascular accident, preeclampsia, eclampsia, spinal deformity, coagulopathy or previous neurological disease were excluded.

They were randomly allocated into two groups each group consisting of 50 patients.

Group A: Patients who received spinal anaesthesia with $27 \mathrm{G}$ quincke needle.

Group B: Patients who received spinal anaesthesia with $25 \mathrm{G}$ quincke needle.

Following intravenous administration of one liter of Hartmann's solution spinal anaesthesia was given in sitting position by the same anaesthesiologist using either 25G or 27G Quincke needle. Standard monitoring (heart rate, blood pressure) was ensured before the start of the anaesthetic procedure and thereafter at five minutes intervals.

A gynaecologist not knowing the type of needle used, did postoperative observations. On the first, second, third and fourth postoperative day patient were enquired for possible occurrence of spinal anaesthesia induced headache. The criteria for PDPH and its severity were assessed by followingcriteria:

Characteristics of $\mathrm{PDPH}^{7}$ :

1. Bilateral headaches.

2. Usually occurs within $24-48$ hours after dural puncture.

3. Worsens within $15 \mathrm{~min}$ of resuming the upright position.

4. Disappears or improves within 30 min of resuming the recumbent position.

Criteria for severity of $\mathrm{PDPH}^{8}$ :

Mild: No limitation of activity

No treatment required

Moderate: Limited activity

Regular analgesics required.

Severe: Confined to bed; anorexic

Unable to feed baby

Women who developed PDPH were managed on pain medications conservatively. Data was analyzed on SPSS version 15. Age height and weight of the patients were presented in Mean $\pm S D$. Frequencies and percentages were presented for American Society of Anaesthesiology (ASA) physical status, PDPH and its severity. Chi square test was applied to compare PDPH and its severity between two groups. $\mathrm{P}<0.05$ was considered level of significant.

\section{Results}

Patient's characteristics are shown in Table-I. Value of age, body weight, height and ASA status are expressed as mean $\pm S D$. There was no statistically significant difference found in age, height, weight, and ASA status between two groups. Successful dural puncture in 1 st attempt was $40(80 \%)$ in group A and $47(94 \%)$ in group B (Table-II). $10(20 \%)$ in group $A$ and $3(6 \%)$ in group $B$ required more than one attempt for successful dural puncture. Statistically significant result was observed $(P>0.05)$.

Table-III shows the incidence of intraoperative complications. In this study 09(18\%) patients in group A and $13(26 \%)$ patients in group B were complicated by intraoperative hypotension. $5(10 \%)$ patients from both group experienced shivering during the intraoperative period. We observed $4(8 \%)$ patients from group $A$ and $6(12 \%)$ patients from group $B$ developed nausea or vomiting. 
The overall incidence of PDPH was $2(4 \%)$ in group A and12 (24\%) in group B as shown in Table-IV. Statistically significant result was observed $(P<0.05)$. Table- $V$ shows the comparison of onset, severity and duration of PDPH in both groups. None of the patients experienced headache on 1st post-operative day in either group. On 2nd post-operative day $1(2 \%)$ and $7(14 \%)$ patients experienced headache in group $A$ and group $B$ respectively. On 3rd postoperative none in group $A$ and $4(8 \%)$ in group $B$ developed headache. $1(2 \%)$ form each group experienced headache on 4 th post-operative day.

Regarding the severity of headache, mild pain was observed in $2(4 \%)$ and $5(10 \%)$ in group $A$ and $B$ respectively. None in the group $A$ experienced moderate to severe headache whereas $4(8 \%)$ and $3(6 \%)$ in group $B$ experienced moderate and severe headache. 2(4\%) in group $A$ and $10(20 \%)$ in group $B$, the headache lasted $25-48$ hours. None in group $A$ and $2(4 \%)$ in group $B$, the headache lasted $>48$ hour.

Table-I: Demographic data of all the patients

\begin{tabular}{|l|l|l|}
\hline Variables & Group A (n=50) & Group B (n=50) \\
\hline Age in years Mean \pm SD & Mean=25.74 \pm 4.4 & Mean $=25.72 \pm 4.3$ \\
\hline Weight in kg Mean \pm SD & Mean $=68 \pm 6.7$ & Mean $=68.34 \pm 7.5$ \\
\hline Height in cm Mean \pm SD & Mean =153.98 \pm 2.7 & Mean $=154.36 \pm 2.8$ \\
\hline ASA I & $41(82 \%)$ & $40(80 \%)$ \\
\hline ASA II & $09(18 \%)$ & $10(20 \%)$ \\
\hline
\end{tabular}

Table-II: Successful dural puncture in first attempt

\begin{tabular}{|c|c|c|c|c|c|}
\hline \multirow[b]{2}{*}{ No of Attempts } & \multicolumn{2}{|l|}{ Group A $(n=50)$} & \multicolumn{2}{|l|}{ Group B $(n=50)$} & \multirow[b]{2}{*}{ P Value } \\
\hline & $\begin{array}{l}\text { Observed Cell Totals } \\
\text { (Expected Cell Totals) } \\
\text { [chi-square statistic] }\end{array}$ & $\%$ & $\begin{array}{l}\text { Observed Cell Totals } \\
\text { (Expected Cell Totals) } \\
\text { [chi-square statistic] }\end{array}$ & $\%$ & \\
\hline 1 attempt & $40(43.50)[0.28]$ & $80 \%$ & $47(43.50)[0.28]$ & $94 \%$ & $0.03752^{*}$ \\
\hline$>1$ attempt & 10 & $20 \%$ & 3 & $6 \%$ & $0.01876^{*}$ \\
\hline
\end{tabular}

Table-III: Incidence of intraoperative complications

\begin{tabular}{|l|l|l|l|l|l|}
\hline \multirow{4}{*}{ Variables } & \multicolumn{3}{|l|}{ Group A (n=50) } & \multicolumn{3}{|l|}{ Group B (n=50) } & \\
\cline { 2 - 5 } & $\begin{array}{l}\text { Observed Cell Totals } \\
\text { (Expected Cell Total) } \\
\text { [Chi-square statistics] }\end{array}$ & $\%$ & $\begin{array}{l}\text { Observed Cell Totals } \\
\text { (Expected Cell Total) } \\
\text { [Chi-square statistics] }\end{array}$ & $\%$ & P Values \\
\hline Hypotension & $9(11.00)[0.36]$ & $18 \%$ & $13(11.00)[0.36]$ & $26 \%$ & $>0.05$ \\
\hline Shivering & $5(5.00)[0.00]$ & $10 \% 5(5.00)[0.00]$ & $10 \%$ & $>0.05$ \\
\hline Nausea/Vomiting & $4(5.00)[0.20]$ & $8 \%$ & $6(5.00)[0.20]$ & $12 \%$ & $>0.05$ \\
\hline No Complain & $32(29)[0.31]$ & $64 \% 26(29.00)[0.31]$ & $52 \%$ & $>0.05$ \\
\hline
\end{tabular}

The result is not significant at $95 \%$ confidence interval.
Table-IV: Comparison of PDPH frequencies in both groups

\begin{tabular}{|c|c|c|c|c|c|}
\hline \multirow[b]{2}{*}{ Variables } & \multicolumn{2}{|l|}{ Group A(n=50) } & \multicolumn{2}{|l|}{ Group B(n=50) } & \multirow[b]{2}{*}{ Pvalue } \\
\hline & $\begin{array}{l}\text { Observed Cell Totals } \\
\text { (Expected Cell Totals) } \\
\text { [chi-square statistic] }\end{array}$ & $\%$ & $\begin{array}{l}\text { Observed Cell Totals } \\
\text { (Expected Cell Totals) } \\
\text { [chi-square statistic] }\end{array}$ & $\%$ & \\
\hline PDPH occurred & $2(7)[3.57]$ & $04 \%$ & $12(7)[3.57]$ & $24 \%$ & \multirow{2}{*}{$P<0.05$} \\
\hline PDPH not occurred & $48(43)[0.58]$ & $96 \%$ & 38 (43) [0.58] & $76 \%$ & \\
\hline
\end{tabular}

The chi-square statistic is 8.3056 . The $p$-value is 0.003952 . This result is significant at $p<0.05$.

Table-V: Comparison of onset, severity and duration of PDPH in both groups

\begin{tabular}{|l|l|c|c|c|c|}
\hline \multicolumn{2}{|c|}{ Variables } & \multicolumn{2}{c|}{ Group A(n=50) } & \multicolumn{2}{c|}{ Group B(n=50) } \\
\cline { 2 - 6 } & & number & percentage & number & percentage \\
\hline \multirow{3}{*}{ Onset } & 1st day & 00 & $00 \%$ & 00 & $00 \%$ \\
\cline { 2 - 6 } & 2nd day & 01 & $02 \%$ & 07 & $14 \%$ \\
\cline { 2 - 6 } & 3rd day & 00 & $00 \%$ & 04 & $08 \%$ \\
\cline { 2 - 6 } & 4 th day & 01 & $02 \%$ & 01 & $02 \%$ \\
\hline \multirow{3}{*}{ Severity } & Mild & 02 & $04 \%$ & 05 & $10 \%$ \\
\cline { 2 - 6 } & Moderate & 00 & $00 \%$ & 04 & $08 \%$ \\
\cline { 2 - 6 } & Severe & 00 & $00 \%$ & 03 & $06 \%$ \\
\hline \multirow{3}{*}{ Duration } & $<24$ hrs. & 00 & $00 \%$ & 00 & $00 \%$ \\
\cline { 2 - 6 } & $25-48$ hrs. & 02 & $04 \%$ & 10 & $20 \%$ \\
\cline { 2 - 6 } & $>48$ hrs. & 00 & $00 \%$ & 02 & $04 \%$ \\
\hline
\end{tabular}

\section{Discussion}

Post dural puncture headache has been regarded as the most common complication of spinal anaesthesia. It occurs most commonly in young female patients, particularly parturient and correlates with the configuration of spinal needle used ${ }^{9}$. In the last 50 years the development of fine gauge spinal needles has enabled a significant reduction in the incidence of $\mathrm{PDPH}^{10}$. In this study we compared $27 \mathrm{G}$ and $25 \mathrm{G}$ Quincke needle for spinal anaesthesia in cesarean section to compare the frequency and severity of PDPH.

In this study, patients of both groups were young healthy parturients. There was no statistically significant difference found in age, height, weight, and ASA status between two groups. There are a few studies, which examine the technical difficulties involved in the use of different spinal needles. In a study by Dittmann and Renkl ${ }^{11}$ the failure rate was $1.4 \%$ and $1.2 \%$ in 29 and 26 gauge groups respectively. In the present study, the same anaesthesiologist with enough experience gave spinal anaesthesia and found that $10(20 \%)$ in group $A$ and $3(6 \%)$ in group $B$ required more than one attempt for successful dural puncture. This is in contrast to study conducted by Dr. Vibhu Srivastava et $\mathrm{al}^{12}$ who observed $10 \%$ failure rate with the $27 \mathrm{G}$ 
Quincke needle. The 25 G Quincke needle was associated with the greatest incidence of successful dural puncture in first attempt (94\%).

In this study, it was observed that hypotension following spinal anaesthesia remains common place in caesarean delivery ( $18 \%$ vs $26 \%)$. Most of the patient was managed with i.v. fluid and oxygen supplementation. Only 2 from group $A$ and 4 patients from group $B$ required ephedrine for correction of hypotension. In contrast to this study, Campbell et al did not observe hypotension in their study and stated that it may be the result of greater prehydration $^{13}$.

In this study, it was observed $5(10 \%)$ patients developed shivering in both groups which correlates the study of Dr Vibhu Srivastava et al ${ }^{12}$. Nausea and vomiting is the another per operative complications of spinal anaesthesia. This nausea vomiting could be a secondary effect relating to maternal hypotension which in turn causes decreased cerebral blood flow. In our study $4(8 \%)$ patients from group $A$ and $6(12 \%)$ patients from group $B$ developed nausea or vomiting and no statistical significant result was observed.

The incidence of PDPH in the present study with the 27G Quincke needle was 4\% and with the 25G Quincke needle was $24 \%$. The difference is statistically significant $(\mathrm{P}<0.05)$. Studies with the 27 gauge Quincke needle in obstetrical patients suggested a PDPH rate of between $1.5 \%$ and $3.7 \%{ }^{14,15}$. This rate is closer to our PDPH rate with the $27 \mathrm{G}$ Quincke needle. The reported PDPH rates, for the 25 gauge Quincke needle vary considerably and it ranges from $7.8 \%$ to $37.2 \%{ }^{16-18}$ which also correlates our study. In contrast to this study, Hwang ${ }^{19}$ observed the incidence of headache was only $3.65 \%$ with the 25G Quincke needle.

Onset of headache was from 24 to 96 hrs after dural puncture. There is no significant difference in between two groups regarding the onset. In a study by Shutt et $\mathrm{al}^{20}$, onset of headache was from 18 to $57 \mathrm{hrs}$ and Anju shah et $\mathrm{al}^{21}$ the onset was from 24 to $96 \mathrm{hrs}$. All the patients in group A, who developed $\mathrm{PDPH}$ had mild headache, none of the patients developed a severe headache or neurological sequelae. In the study of Dittmann and Rankl ${ }^{11}$ a decreased severity of headache was noted in the $29 \mathrm{G}$ group Quincke needle. In group B, 5 patients developed mild headache, 4 patients developed moderate headache and 3 patients developed severe headache. Moderate form of headache was observed in 1 and 6 patients in 29 and $26 \mathrm{G}$ groups respectively by Shah et $\mathrm{al}^{21}$. There was no difference regarding the duration of headache in between two groups.

In this study, headache was relieved by reassurance, rest, analgesics and IV fluids. When the present study is compared with others using the 27G Quincke needle and 25G Quincke needle it appears that the thicker the lumber puncture needles, higher could be incidence of $\mathrm{PDPH}^{12,21,23}$.

\section{Conclusion}

The size of dural tear is directly proportionate to the amount of CSF leakage. As a smaller needle diameter produces a smaller tear in the dura, there is less potential for leakage and incidence of headache after lumber puncture. In the present study the frequency and severity of PDPH was lower in $27 \mathrm{G}$ Quincke needle as compared to $25 \mathrm{G}$ Quincke needle though it had a higher failure rate of successful lumber puncture in first attempt. For spinal anaesthesia $27 \mathrm{G}$ Quincke needle should be used.

\section{References}

1. Di Cianni S, Rossi M, Casati A et al. Spinal anaesthesia: An evergreen technique. Acta Biomed 2002; 79:215-22.

2. Olsen KS. Epidural blood patch in the treatment of post-lumbar puncture headache. Pain 1987; 30(3): 293-301.

3. Kaukinen S, Kaukinen L, Kannisto K. The prevention of headache following spinal anaesthesia. Ann Chir Gynaecol 1981; 70:107-11.

4. Meyer-Hamme K, Stratmann D, Watermann WF. Postspinal headache- A clinical problem. Reg Anaesth 1979; 2:77-80.

5. Morewood GH. A rational approach to the cause, prevention and treatment of postdural puncture headache. CMAJ 1993; 149:1087-93.

6. Dietrich M, Perkin GD. Post lumber puncture headache syndrome. Academic Press 1996:59-63. 
7. Olsen J, Bousser MG, Diener HC et al. The international Classification of Headache Disorders. 2nd ed. Cephalagia 2004; 160:149-60.

8. Courtney MA, Bader AM, Hartwell B et al. Preoperative analgesia with subarachnoid sufentanil administration. Regional anaesthesia 1992; 17:274-8.

9. Brown LD. Atlas of regional anaesthesia. 2nd ed. New York: WB Saunders Company 1992:305-9.

10. Hunt CO. Spinal anesthesia for obstetrics. Int anesthesiol Clin 1989; 27:26-30.

11. Dittmann M, Schaefer HG, Renkl F. Spinal anaesthesia with 29 gauge Quincke point needles and post dural puncture headache in 2,378 patients. Acta Anaesthesiol Scand 1994; 38:691-3.

12. Srivastuva V, Jindal P, Sharma JP. Study of Post Dural Puncture Headache with 27 G Quincke and Whitacre Needles in Obstetrics/Non-Obstetrics patients. MEJ Anes 2010; 20(5):709-17.

13. Campbell DC, Douglas MJ, Pavy TJ et al. Comparison of the 25-gauge Whitacre with the 24gauge Sprotte spinal needle for elective caesarean section, cost implications. Can J Anaesth 1994; 40:1131-5.

14. Flanagan JF, Kumatta D, Black D. Comparison of 24 gauge Sprotte and 27 gauge Quincke needle on the incidence of post dural puncture headache. Anesth Analg 1991:72-5.

15. Kang SB, Goodnough DE, Lee YK et al. Comparison of 26-G and 27-G needles for spinal anesthesia for ambulatory surgery patients. Anesthesiology 1992; 76:734-8.
16. Flaatten H, Rodt S, Rosland J. Postoperative headache in young patients after spinal anaesthesia. Anaesthesia 1987; 42:202-5.

17. Sarma V J, Bostrom U. Intrathecal anaesthesia for day-care surgery. A retrospective study of 160 cases using 25-gauge and 26-gauge spinal needles. Anaesthesia 1990; 45:769-71.

18. Crawford JS. Experience with spinal analgesia in a British obstetric unit. Br J Anaesth 1979; 51:531-5.

19. Hwang JJ, Ho ST, Wang JJ et al. PDPH in Caesarean section. Comparison of 25 gaugewhitacre with 25 and $26 \mathrm{G}$ quincke needle. Acta Anaesthesiol Sin 1997; 35(1):33-7.

20. Shutt, LE, Valentine SJ, Wee MYK et al. Spinal anaesthesia for Caesarean section - Comparison of 22 gauge and 25 gauge Whitacre needle with 26 gauge quincke needles". Br J Anaesth 1992; 69:589.

21. Shah A, Bhatia PK, Tulsiani KL. Post Dural Puncture Headache in Caesarean Section- A Comparative Study using 25G Quinke, $27 \mathrm{G}$ Quinke and $27 \mathrm{G}$ Whitacre Needle. Indian J Anaesth 2002; 46(5):373-7.

22. Lynch J, Krings-Earnst I, Strick K et al. Use of a 25 gauge whitacre needle to reduce the incidence of post dural puncture headache. Br J Anaesth 1991; 67:690.

23. Guerts JW, Haanschoten MC, Van Wgik RM et al. Post-dural puncture headache in young patients. A comparative study between the use of $0.52 \mathrm{~mm}$ (25-gauge) and $0.33 \mathrm{~mm}$ (29-gauge) spinal needles. Acta Anaesthesiol Scand 1990; 34:350-3. 